\title{
Foreword: Symposium on Vice and the Criminal Law
}

\author{
Stuart P. Green
}

Published online: 5 August 2012

(C) Springer Science+Business Media B.V. 2012

An obvious, if somewhat perverse, attraction of criminal law for those who study it is that it involves the regulation of some of the darkest and most disturbing aspects of human behavior. If one is interested in observing the most wrongful, harmful, and anti-social kinds of conduct in which people are capable of engaging, the criminal law offers as promising a place as any to start.

Moral philosophy offers another body of work we might look to for insight into the evil that men do. Although moral philosophers have traditionally been interested more in the right and the good than the wrong and the bad, there is nevertheless a significant body of scholarship focused on the latter. This is true even, or perhaps especially, in the case of virtue theory, which, owing to its late twentieth century revival, can now plausibly claim to be the third major stream of Western moral theory, along with utilitarianism and Kantianism (see Anscombe 1958; Foot 1978; MacIntyre 1985). While much of this literature has focused on the ways in which our private and public lives are supposedly enhanced by the development of virtue, there is also an interesting, if modest, body of scholarship focused on how our lives are degraded by what is normally characterized as its opposite-namely, vice (see Skhlar 1984; Schimmel 1997; Taylor 2006).

So, the question arises: what exactly is, or should be, the relationship between vice and the criminal law? The six papers included in this symposium-written by leading scholars in law, philosophy, and the social sciences-are each, in their own way, addressed to this question. This brief introduction offers a roadmap to these papers and a highly preliminary framework for thinking about the vice/crime connection.

\section{The Concept of Vice}

The terms "vice" and "vicious" can be understood in a number of different senses, both general and specific. First, vice can refer to an unspecified moral failing or bad character trait. A person who is "vicious"-literally, "full of vice"-is one whose character reflects

S. P. Green $(\bowtie)$

Rutgers University School of Law-Newark, Newark, NJ, US

e-mail: sgreen@kinoy.rutgers.edu 
one or more moral failings. Being vicious can, in modern usage, also have the special connotation of being savage or cruel. Vicious animals are sometimes spoken of in this way (though this usage is somewhat surprising given the fact that animals, presumably, are not properly regarded as genuine moral agents). The term "vice" is also used to refer to unspecified immoral practices, conduct, or habits that are associated with bad character traits. Used in this sense, an act that is vicious is an act that is reflective of the actor's bad character.

More narrowly, and perhaps more commonly, vice can refer to one or more of a list of specific defects in character, or specific kinds of bad acts associated with those defective traits. One of the most common ways of conceptualizing the vices, characteristic especially of Aristotle, is in terms of the extremes between which virtue, as a mean, can be located. For example, the vices of stinginess, on the one hand, and prodigality, on the other, can be understood as the extremes between which the virtue of generosity can be located. Similarly, courage can be understood as the mean between fear and rashness; prudence the mean between over-caution and insufficient caution; humility the mean between shame and pride; moderation the mean between insensibility and self-indulgence; tolerance the mean between narrow-mindedness and over-acceptance; and so forth. ${ }^{1}$

Different religious traditions have formulated their own approach to the vices. Medieval and early Renaissance Christian theology often spoke in terms of Seven Deadly Vices or Sins: pride, envy, lust, sloth, anger, gluttony, and greed. "Vice" in this sense referred to a specific list of character traits that were thought to reflect flaws in the soul's pre-Lapsarian capacity for goodness, while "sins" were the specific acts associated with those vices (Schimmel 1997, at 15-18). Jewish ethics developed its own approach to the vices and sins, many of which are listed in the Ashamnu, the shorter confessional in the Yom Kippur liturgy, dating to the 8 th century. ${ }^{2}$

Lists of vices have been compiled and commented on by more modern authorities as well. Montaigne famously identified cruelty as the "ultimate" vice (de Montaigne c. 15781580). The political theorist Judith Shklar wrote about what she called the "ordinary vices"-hypocrisy, snobbery, treachery, and misanthropy (1984). There have also been attempts to update the list of vices and sins to reflect the problems of a modern world, including behaviors such as polluting the environment, fostering social injustice, and pedophilia. $^{3}$

One of the advantages of thinking about morality in terms of vice and virtue, I would argue, is that doing so offers a psychological richness that may elude us when morality is considered in terms of more generic concepts like duty or utility. As Gabrielle Taylor has put it, vice and virtue consist in acting in certain "patterned ways" (2006, at 1). "The agent is seen as concerned with how to conduct her own life, and therefore is approaching ethical questions not as isolated occurrences to be given impartial and universally applicable solutions, but as being embedded in a web of attitudes, interests, and preferences" (Id. at 2). When we talk about courage and cowardice, avarice and generosity, pride and modesty,

\footnotetext{
1 This approach is particularly associated with Aristotle, who famously described the proper approach to bodily pleasure as lying somewhere between gluttony and lust, on the one hand, and abstinence, on the other (Aristotle 2009; see also MacIntyre 1985, at 155).

2 These include stubbornness of heart, unchastity, talebearing, breach of trust, arrogance, slander, insolence, and insincere confession (Goodman 1992, at 56-59).

3 Vatican updates seven deadly sins for modern world. Herald-Sun (Melbourne) (March 10, 2008), http:// www.heraldsun.com.au/news/victoria/seven-deadly-sins-becomes-14-at-least/story-e6frf7lf-1111115759198.
} 
we tap into a rich vein of human character traits that are familiar to us from literature, art, psychology, self-reflection, and our own life experiences.

\section{Vice and Crime}

The very focus on character traits that makes virtue and vice theory such a promising means of thinking about morality also makes it problematic in the context of criminal law. The most basic problem is that, as Antony Duff has put it, "criminal liability is, at least paradigmatically, imposed not for choices, or character traits, or vices, but for actions" (2002, at 183). A second, closely related, problem - at least for those who subscribe to a liberal theory of the state-is that we are loath to use law, especially criminal law, as a vehicle to shape character.

But to accept the notion that the criminal law has little or no legitimate role in shaping character need not mean that there can be no meaningful role for vice within the theory of criminal law. If we think of the vices not in the context of character traits per se, but rather in terms of the conduct associated with such traits, then an appropriate role for vice within criminal law theory might be found.

There are at least two broad contexts in which this might occur. We can begin with the simple observation that many forms of vice can, when acted upon, lead to criminal conduct. For example, cruelty can (but of course need not) lead to serious crimes such as terrorism, torture, murder, assault, rape, mayhem, kidnapping, human trafficking, and the like. Greed, when pursued in illegal ways (such as theft or insider trading or, perhaps, nonsanctioned gambling) is treated as a crime, but not when pursued by lawful means (such as investment banking - in that context, it is richly rewarded). Lust can also lead to criminal behavior: this was true in connection with now outmoded offenses like fornication, adultery, and sodomy; it is arguably still true with respect to crimes like incest, child pornography, and (more controversially) rape. Intolerance, racism, sexism, bigotry, and the like, though certainly viewed as serious vices, are not normally illegal except in the context of hate crimes and hate speech laws (at least in those jurisdictions that recognize such offenses) and perhaps in cases of sexual harassment (though that is typically, a civil, rather than criminal, wrong). Sloth per se is normally not a crime at all, though it was sloth that arguably was the subject of once-common vagrancy laws, and it is concern with sloth (and possibly gluttony) that may underlie common prohibitions on the use of drugs and alcohol and perhaps gambling.

Exploring the myriad ways in which such individual vices inform the moral content of the criminal law seems like an exercise that (at some point, though not here) would be worth pursuing. ${ }^{4}$ Taken as a whole, however, there is nothing about such vice-related crime that is particularly distinctive. The great majority of crimes (a possible exception is various strict liability and regulatory crimes) in some way involve vice-like behavior, and presumably ought to do so if they are to meet the demands of retributivism.

This is not, however, the normal way we talk about "vice crimes." Normally, we reserve the term for a relatively discrete collection of offenses that includes, or has traditionally included, laws criminalizing drug use and distribution, alcohol consumption and sale, prostitution, gambling, pornography, and sexual offenses such as incest, fornication, adultery, and sodomy - in other words, the kinds of acts with which police "vice squads"

\footnotetext{
${ }^{4}$ It might also be worth asking why certain vices - think of hypocrisy or vanity or stinginess-have never been serious candidates for criminalization.
} 
have traditionally been concerned. So, what is there about this category of offenses that makes it worthy of special interest? The question is a complex one that cannot be answered fully in this limited forum, but I would offer, as a start, three characteristics that most vice crimes, used in this more familiar, narrow, sense, seem to share:

First, the vice crimes typically cause either no harm at all or harms only to self; or, if they do cause harms to others, such harm is consensual. For example, the direct harm, if any, caused by illegal drug use is ordinarily to the drug user rather than to any third party (though, of course, some drug use causes secondary harms to the drug abuser's family or his community). As for sex-related offenses such as fornication, sado-masochistic activities, or offering oneself for sexual sale, these involve either consensual harms or no harm at all. Thus, we can think of the "vice crimes" as those that are not easily captured by the harm principle: they involve "mere" immorality rather than obviously harmful immorality.

Second, vice crimes tend to involve conduct the wrongfulness vel non of which is (at least now, even if it has not always been) the subject of genuine disagreement within the larger community - largely because the conduct is perceived as harmless. Rather than a concern with cognizable social harm, such legislation is often driven more by a sense of disgust or revulsion. In addition, the criminalization of vice is often premised on religious values that may not be universally held.

Third, vice crimes often involve behavior that is addictive or compulsive or in some sense "unhealthy." This is frequently true in the case of drug, alcohol, pornography, and gambling-related offenses, and is also probably true of certain sex-related vice crimes, such as prostitution.

Each of these three characteristics in turn contributes to the air of controversy that surrounds the vice crimes. For example, given the debate over whether the underlying behavior is itself wrongful, it is hardly surprising that the criminalization of such behavior would also be controversial. Vice crime laws, moreover, pose one of the most significant challenges to the harm principle. The criminal law provides the most coercive and intrusive exercise of state power one can have in a liberal society. Liberals normally maintain that the state should have no authority to criminalize (or even prohibit) conduct that is not harmful at all, or harmful only to self; legal moralists, of course, disagree. Finally, behavior that is in some sense addictive or compelled, rather than the result of free will, also poses problems for the criminal law, application of which is premised on the idea that offenders should be free moral agents.

\section{The Symposium}

On September 16, 2011, a group of leading scholars-in law, philosophy, and social science — gathered at Rutgers Law School, in Newark, to discuss a collection of papers that explored a variety of issues related to the criminalization of vice. ${ }^{5}$ Taken together, the papers address three basic issues: First, what is special about vice-related conduct that makes its criminalization or other regulation controversial? Second, what kinds of vicerelated conduct are appropriate for criminalization or other regulation, and which are not?

\footnotetext{
5 The workshop included, in addition to the main papers, excellent commentaries by Michael Cahill, Luis Chiesa, Jeffrey Fagan, Adil Haque, Kyron Huigens, and Youngjae Lee.
} 
Third, assuming that the state has a legitimate role in regulating a given form of vicerelated behavior, what is the proper mode of such regulation: is it the criminal law or something else?

The first question is addressed in Michelle Madden Dempsey's insightful piece on the normative force of consent. As Dempsey points out, one of the strands that underlies the liberal critique of vice crimes is the notion that such crimes involve conduct that is victimless (or, at least involves no third party victims). This in turn raises the more fundamental question as to why a victim's consent should be deemed to make conduct harmless, or at least not wrongful. According to Dempsey, most of the leading accounts of the volenti maxim 6 simply "report[] on the outcome that consent purports to bring about" (2012, at-). They fail to show us how consent actually works its so-called "magic." In her piece, Dempsey sets out to do just that. She begins by explaining the circumstances in which consent is called for-namely, she says, when the actor's conduct calls for justification, and when a reason a justification is needed is grounded in the consenter's wellbeing. She then argues that consent constitutes an "exclusionary permission to disregard reasons against acting that are grounded in the well-being of the person who consented" (Id. at-). In normal cases, when the exclusionary option is taken up by the actor whose conduct calls for the other's consent, the moral quality of the actor's conduct is transformed such that the conduct no longer constitutes a wrong against the second party. Dempsey also describes two cases in which she believes the actor's conduct remains a wrong notwithstanding the victim's consent: where the actor is "consent-insensitive" to the rational force of the victim's consent (the example Dempsey gives is prostitute users, who are often "indifferent to the normative force of [the prostitute's] consent" (Id. at-)); and where the actor is acting out of sadistic motives.

The second question - concerning the kinds of vice appropriate for legal prohibition - is addressed particularly in the contributions of Peter de Marneffe, Vera Bergelson, and Ekow Yankah.

De Marneffe's interest is the familiar one of drug and prostitution laws, but his take on these offenses is quite novel. After offering his own attempt to define vice crime, de Marneffe distinguishes between two different kinds of vice laws. Some laws make it a crime to use drugs or sell one's own sexual services, while others make it a crime to manufacture or sell drugs or sell others' sexual services by means of operating a brothel or escort service. "Decriminalization" occurs when criminal penalties are eliminated for using drugs or possessing small quantities of drugs or for the sale of one's own sexual services. "Legalization" occurs where there are no criminal penalties for manufacturing, selling, or possessing large quantities of drugs or for operating a brothel or escort service. De Marneffe argues that laws making drugs and prostitution criminal violate our moral rights in ways that laws making drugs and prostitution non-legal do not (2012, at-). The former, unlike the latter, deprive people of control over their own minds and bodies. For this reason, he says, drugs and prostitution should be decriminalized. Whether they should also be legalized is a separate question. The originality of de Marneffe's approach lies in its focus on the violation of the offender's self-sovereignty effected by vice law, rather than the more familiar claim that the underlying conduct is harmless or that such laws are paternalistic.

Even those liberals who disapprove of laws that criminalize drug use or prostitution might still find themselves sympathetic to the idea of criminalizing the practice of incest. Bergelson, in her provocative contribution to the symposium, argues that they would be wrong to do so. Bergelson examines what she regards as the main justifications that have

${ }^{6}$ Volenti non fit injuria-to one who consents, no wrong is done. 
been offered for incest laws - respecting religion and universal tradition, avoiding genetic abnormalities, protecting the family unit, preventing sexual abuse and sexual imposition, precluding immorality, and revulsion and disgust-and finds them wanting. She argues, among other things, that such laws are over-inclusive insofar as they apply to incestuous couples who use contraceptives or have been sterilized, and to the extent that they bar not just sexual intercourse but other forms of sexual intimacy as well (2012, at-). Moreover, she says, the fact that most people find incest revolting, the object of a powerful taboo, is not sufficient to justify criminalization absent a showing that it is truly harmful or violative of participants' dignity. As for those cases in which incest involves coercion or force-as where, say, a step-father has sex with a young step-child-Bergelson says they are better dealt with straightforwardly through rape and sexual assault laws, rather than through overly broad incest laws that would also apply to adult consensual relationships.

Yankah, in his stimulating contribution, takes yet another approach to the vice crimes. $\mathrm{He}$ argues that both liberal theorists and legal moralists err in focusing on the use of criminal law to suppress personal vices (like lust, sloth, and greed). Instead, Yankah seeks to follow Aristotle in exploring what he calls the "legal vices-particularly, the manipulation of law to serve factional interests" (2012, at-). Although Aristotle may have been attracted to the idea of using law to mold private character, Yankah says, he ultimately recognized that any attempt to do so would be futile. As Yankah puts it, "[1]aw might give people a reason to avoid bad acts because they feared punishment but it could not be counted on to instill true virtue in those who did not already seek it" (Id. at-). Instead, Aristotle's (and Yankah's) real interest is in using law to promote public virtue-in sharing in the burdens of governing, giving citizens the breathing room to pursue their own projects, preventing factionalism, promoting respect for the law, and so forth. In deeply vice-ridden societies like Nazi Germany, Apartheid South Africa, and the ante-bellum and Jim Crow South, says Yankah, factionalism was at its strongest and legal hypocrisy and contempt for the law at their most corrosive.

Finally, the question of exactly how society should address vice-like behavior-whether by means of criminal sanctions or some other kind of government regulation-is one that lies at the heart of the fascinating contributions from Rob MacCoun and Jim Leitzel.

MacCoun, for his part, is interested in two contrasting approaches that society can take to vice-related behavior. One involves trying to reduce the prevalence of such conduct, typically by prohibition or criminal sanctions; the other consists of trying to reduce the harm associated with the conduct, by making the conduct less dangerous (say, by giving heroin users clean needles or providing prostitutes with free condoms, and the like). MacCoun seeks to measure lay persons' beliefs about which of these two kinds of approach society should take with respect to a range of different kinds of potentially dangerous behavior, including heroin consumption, alcoholism, tobacco use, skateboarding, teen sex, illegal immigration, air pollution, and consumption of fast food. MacCoun finds that people who view themselves as social and political conservatives are more likely than those who think of themselves as liberals to favor prevalence reduction over harm reduction, at least with respect to most of the behaviors considered (2012, at-). MacCoun's piece also offers an interesting insight into the question of what makes vice crimes distinctive in the first place: he finds that people's judgments about whether society should use prohibition or harm reduction are largely influenced by the extent to which such conduct makes them feel anger or disgust. Where these emotions were strongly felt, subjects were much less likely to be attracted by the prospect of harm reduction.

Leitzel is also interested in the fertile middle ground between outright prohibition and total legalization. Somewhere in the middle, he says, lie less coercive, more "finely tuned" 
means of reducing vice-related behaviors and their associated harms (2012, at-). Leitzel's particular interest is in the use of buyer licensing and exclusion techniques as a way to reduce harmful drug and alcohol use. Licensing consists of requiring users to jump through various hoops-like being of a minimum age, receiving a recommendation from a doctor, and staying out of trouble when using drugs-before they will be permitted to make a purchase. Exclusion goes a step further: Individual users who abuse alcohol or drugs or who engage in problem gambling can lose their right to purchase such products or services temporarily or even permanently. Leitzel examines a number of contexts, both historical and contemporary, in which licensing and exclusion approaches have enjoyed a degree of success, and argues that as we move toward a less punitive regime for controlling drug use, both approaches are worth considering.

It has been more than 50 years since Hart and Devlin first crossed swords over the criminalization of harmless immoralities. In the interim, society has experienced major changes in the way it regards and regulates various forms of vice-related behavior (in the case of homosexuality, for example, the concept of "vice" is no longer even apposite); moral philosophy has witnessed a significant revival of interest in virtue theory; and the social sciences have developed innovative new methods for assessing how various controversial behaviors are viewed by the public. Reflecting these and other developments, the six essays contained in this symposium offer a range of ingenious and insightful ways to think about this perennially controversial set of offenses.

\section{References}

Anscombe, G. E. M. (1958). Modern moral philosophy. Philosophy, 33, 1.

Aristotle. (2009) In L. Brown (Ed.), Nichomachean ethics (W. D. Ross, Trans.). Oxford: Oxford University Press.

Bergelson, V. (2012). Vice is nice but incest is best: The problem of a moral taboo. Criminal Law and Philosophy,. doi:10.1007/s11572-012-9158-9.

de Marneffe, P. (2012). Vice laws and self-sovereignty. Criminal Law and Philosophy,. doi:10.1007/s11572012-9157-X.

de Montaigne, M. On Cruelty (c. 1578-1580). The essays of Montaigne. (E. J. Trechman, Trans.) vol. 1. New York: Oxford University Press. p. 421.

Dempsey, M. M. (2012). Victimless conduct and the volenti maxim: How consent works. Criminal Law and Philosophy, doi:10.1007/s11572-012-9162-0.

Devlin, P. (1965). The enforcement of morals. Oxford: Oxford University Press.

Duff, R. A. (2002). Virtue, vice, and criminal liability: Do we want an Aristotelian criminal law? Buffalo Criminal Law Review, 6, 147.

Foot, P. (1978). Virtues and vices. Oxford: Basil Blackwell.

Goodman, P. (1992). Yom Kippur anthology. Philadelphia: Jewish Publication Society.

Hart, H. L. A. (1963). Law, liberty, and morality. Stanford, CA: Stanford University Press.

Leitzel, J. (2012). Toward drug control: Exclusion and buyer licensing. Criminal Law and Philosophy,. doi: $10.1007 / \mathrm{s} 11572-012-9155-\mathrm{z}$.

MacCoun, R. (2012). Moral outrage and opposition to harm reduction. Criminal Law and Philosophy,. doi: 10.1007/s11572-012-9154-0.

MacIntyre, A. (2d ed. 1985). After virtue: A study in moral theory. Notre Dame, IN: University of Notre Dame Press.

Schimmel, S. (paperback ed. 1997). The seven deadly sins. New York: Oxford University Press.

Shklar, Judith. (1984). Ordinary vices. Cambridge, MA: Bellknap Press.

Taylor, G. (2006). Deadly vices. Oxford: Oxford University Press.

Yankah, E. N. (2012). Legal vice and civic virtue: Vice crimes, republicanism and the corruption of lawfulness. Criminal Law and Philosophy,. doi:10.1007/s11572-012-9161-1. 